\title{
Article
}

\section{Effect of Foliar Antibroadleaf Herbicides on Fat Content in Seeds of Various Cotton (Gossypium Hirsutum L.) Cultivars}

\author{
Teodora D. Barakova ${ }^{1}$, Grozi D. Delchev ${ }^{2, *}$ and Neli K. Valkova ${ }^{1}$ \\ 1 Field Crops Institute, 2 Georgi Dimitrov Street, 6200, Chirpan, Bulgaria; tedi_mendeva@abv.bg (T.B.); \\ iptp@abv.bg (N.V.) \\ 2 Department of Plant Production, Faculty of Agriculture, Trakia University, Students' Campus, 6000, Stara \\ Zagora, Bulgaria; delchevgd@dir.bg \\ * Correspondence: e-mail: delchevgd@dir.bg; Tel.: +359-894-615-068
}

\begin{abstract}
In this study was investigate the effect of vegetative treatment with the herbicides Basagran 480 SL, Pulsar 40 and Express 50 WG on the fat content of seeds of different Bulgarian cotton cultivars. The experiment was carried out with twelve Bulgarian cotton cultivars belonging to Gossypium hirsutum L. For the first time in the world, cotton cultivars resistant to herbicides Basagran 480 SL (bentazone), Pulsar 40 (imazamox) and Express 50 WG (tribenuron-methyl) have been established. They are applied at the bud formation stage of cotton. Fat content in cotton seeds was determined by extraction - SR ISO 6492. For the first time in the world it has been established that in the vegetative treatment with herbicides the most valuable with regard to cottonseed fat content are all cultivars treated with Basagran 480 SL, except Chirpan-539 and Helius. It has been established for the first time that from the point of view of growing technology with vegetative treatment with the herbicide Express 50 WG, the most valuable are the cultivars Chirpan-539, Helius, Trakia, Vicky, Philipopolis, IPK-Veno, Boyana, Avangard, Natalia. None of the cultivars is highly rated when treated with the herbicide Pulsar 40 with regard to fat content in seeds.
\end{abstract}

Keywords: cotton; vegetation antibroadleaf herbicides; cultivars; fat content

\section{Introduction}

Cotton is a crop characterized by long vegetation period and a poor competitive ability to weeds. Because of this, it is highly sensitive to weed spread from the earliest stages of its development.

Problems with primary weed spread in cotton are solved to a considerable extent $[6,8]$. The issue of secondary weed spread of annual and perennial graminaceous weeds during cotton vegetation is also solved to a great extent by using antigraminaceous herbicides $[9,10]$.

Data on herbicides for efficient control of secondary emerging annual and perennial broadleaf weeds in conventional cotton growing technology are rather scarce even on a global scale. Effective herbicides for their control in cotton are still being sought. In the application of vegetative anti-broadleaf herbicides in conventional technology, there are often manifestations of phytotoxicity $[3,4]$.

Information on glyphosate-tolerant cotton cultivars is presented [11,19]. In them control of all weeds - graminaceous and broadleaf, annual and perennial is completely solved by the use of total herbicides based on glyphosate (Roundup Ready technology) or glufosinate (Liberty Link technology). These technologies are widely used in major cotton-producing countries. However, these cultivars are GMOs and are banned within the territory of the European Union, incl. Bulgaria. This makes the present study particularly relevant not only for Bulgaria, but also for all cotton producing countries within the European Union. 
The seeds of cotton are quite rich in fat - 17-23\%. Cotton oil is one of the most important semi-dry oils in the world used for alimentary and technical purposes.

Worldwide, there are many studies on the fat content in cotton seed, its quality and its purpose $[1,2,7,12,15,16,20]$. Scientific literature does not yet know whether treatment with herbicides during cotton growing affects the fat content of cotton seeds.

The purpose of this study is to investigate the effect of vegetative treatment with the herbicides Basagran 480 SL, Pulsar 40 and Express 50 WG on the fat content of seeds of different Bulgarian cotton (Gossypium hirsutum L.) cultivars.

\section{Materials and Methods}

During the period 2013-2015 a field experiment was conducted at the experimental field of the Field Crops Institute - Chirpan, in non-irrigated conditions, on Pellic Vertisol soil type. The experiment was carried out with twelve Bulgarian cotton cultivars - Chirpan-539, Helius, Trakia, Vicky, Philipopolis, IPK-Veno, Boyana, Avangard, Natalia, Darmy, Dorina and Nelina belonging to Gossypium hirsutum L. species. These cultivars are not genetically modified. They have been created by interspecies hybridization and experimental mutagenesis.

Herbicides Basagran 480 SL (bentazone), Pulsar 40 (imazamox) and Express 50 VG (tribenuron-methyl) were studied. They are applied at the bud formation stage of cotton. Spraying was made with a hand back sprayer with a work solution of $30 \mathrm{l} / \mathrm{da}$. The applied herbicides have been applied against the background of the herbicidal combination Dual Gold 960 EC (s-metolachlor) + Goal 2 E (oxyfluorfen), applied after sowing pre-emergence to control primary weeding of cotton. The experiment variants are given in Table 1.

Fat content in cotton seeds was determined by extraction - SR ISO 6492. The seeds were taken from cotton treated during vegetation with the relevant herbicides.

Statistical evaluation to rate the representativeness and reliable effect of the studied parameters has been applied through dispersion analysis and Fischer's parametric criterion F [5,18]. In the variance analysis the ANOVA123 software is used for calculation [14].

The selectivity of herbicides was established through their effect on grain yield and the following variances have been calculated:

Shukla stability variance $\left(\sigma_{\mathrm{i}}^{2}\right)$

$$
S h-\sigma_{i}^{2}=[1 /(e-1)(t-1)(t-2)] \times\left[t(t-1) \sum_{j=1}^{s}\left(u_{i j}-\bar{u}_{i}\right)^{2}-\sum_{i=1}^{t} \sum_{j=1}^{s}\left(u_{i j}-\bar{u}_{i}\right)^{2}\right]
$$

where:

$$
u_{i j}=X_{i j}-\bar{X}_{. j}
$$

$X_{i j}=$ observed trait value of $i^{\text {th }}$ cultivar in $j^{\text {th }}$ environment,

$\bar{X}_{. j}=$ mean of all cultivars in $j^{\text {th }}$ environment,

$$
\bar{u}_{i .}=\sum_{j=1}^{m} u_{i j} / e
$$

$e=$ number of environments,

$t=$ number of cultivars.

In this study, calculation of adjusted stability variance $\left(S h-S_{i}{ }^{2}\right)$ was necessary, because the heterogeneity term was significant $(P<0.01)$. The stability statistic $\mathrm{Sh}-\mathrm{Si}^{2}$ calculated following removal of heterogeneity due to environmental index $\left(Z_{j}=\bar{X}_{. j}-\bar{X}_{. .}\right)$as a covariate from GE interaction variance, where $\bar{X}_{. j}=$ mean of all cultivars in $j^{\text {th }}$ environment and $\bar{X}_{. .}=$mean of all cultivars across all environments, using the following equation (Shukla 1972): 
Table 1. Investigated variants.

\begin{tabular}{|c|c|c|c|c|c|c|}
\hline \multicolumn{6}{|c|}{ Herbicides } & \multirow{3}{*}{$\begin{array}{c}\text { Cultivars } \\
\text { (no GMOs) }\end{array}$} \\
\hline \multicolumn{3}{|c|}{ After sowing, before emergence } & \multicolumn{3}{|c|}{ During budding stage } & \\
\hline Herbicide & $\begin{array}{c}\text { Active } \\
\text { substance }\end{array}$ & Dose & Herbicide & Active substance & Dose & \\
\hline \multirow{3}{*}{$\begin{array}{c}\text { Dual gold } \\
960 \mathrm{EK} \\
+ \\
\text { Goal } \\
2 \mathrm{E}\end{array}$} & \multirow{3}{*}{$\begin{array}{c}\text { s-metolachlor } \\
+ \\
\text { oxifluorfen }\end{array}$} & \multirow{3}{*}{$\begin{array}{c}1.2 \text { 1/ha } \\
+ \\
1.51 / h a\end{array}$} & $\begin{array}{c}\text { Basagran } \\
480 \mathrm{SL}\end{array}$ & bentazone & $1.5 \mathrm{l} / \mathrm{ha}$ & $\begin{array}{c}\text { Chirpan-539 } \\
\text { Helius } \\
\text { Trakia } \\
\text { Vicky } \\
\text { Philipopolis } \\
\text { IPK-Veno } \\
\text { Boyana } \\
\text { Avangard } \\
\text { Natalia } \\
\text { Darmy } \\
\text { Dorina } \\
\text { Nelina }\end{array}$ \\
\hline & & & $\begin{array}{c}\text { Pulsar } \\
40\end{array}$ & imazamox & $1.2 \mathrm{l} / \mathrm{ha}$ & $\begin{array}{c}\text { Chirpan-539 } \\
\text { Helius } \\
\text { Trakia } \\
\text { Vicky } \\
\text { Philipopolis } \\
\text { IPK-Veno } \\
\text { Boyana } \\
\text { Avangard } \\
\text { Natalia } \\
\text { Darmy } \\
\text { Dorina } \\
\text { Nelina }\end{array}$ \\
\hline & & & $\begin{array}{c}\text { Express } \\
50 \mathrm{WG}\end{array}$ & tribenuron-methyl & $50 \mathrm{~g} / \mathrm{ha}$ & $\begin{array}{c}\text { Chirpan-539 } \\
\text { Helius } \\
\text { Trakia } \\
\text { Vicky } \\
\text { Philipopolis } \\
\text { IPK-Veno } \\
\text { Boyana } \\
\text { Avangard } \\
\text { Natalia } \\
\text { Darmy } \\
\text { Dorina } \\
\text { Nelina }\end{array}$ \\
\hline
\end{tabular}

$$
S h-S_{i}^{2}=[t /(t-2)(e-2)] \times\left[s_{i}-\sum_{i=1}^{t} s_{i} / t(t-1)\right]
$$

where:

$$
\begin{gathered}
s_{i}=\sum_{j=1}^{s}\left(u_{i j}-\bar{u}_{i .}-b_{i} Z_{j}\right)^{2} \\
b_{i}=\sum_{j=1}^{s}\left[\left(u_{i j}-u_{i .}\right) Z_{j}\right] / \sum_{j=1}^{s} Z_{j}^{2}
\end{gathered}
$$

Cultivar stability across multiple years and locations also was evaluated using the ecovalence (Wi) (Wricke 1962):

$$
W_{i}^{2}=\sum_{i=1}^{t}\left(X_{i j}-\bar{X}_{i .}-\bar{X}_{. j}+\bar{X}_{. .}\right)^{2}
$$

Greatest stability is when $W=W_{i}^{2}=0$. 
For grain yields stability parameters have been calculated. Stability variances $\left(\sigma_{i}^{2}\right.$ and $\left.\mathrm{Si}^{2}\right)$ by Shukla [17] and ecovalence $W_{i}$ by Wricke [21] show what portion of variation related to interaction of the preparations and years are accounted by the specific variant.

Through the stability criterion $\left(\mathrm{Y}_{\mathrm{i}}\right)$ of Kang [13] the value of each variant has been shown by simultaneous taking into account the parameter value and the stability of the variant. The value of that criterion is that by using non-parametric methods and statistical reliability of differences we obtain a combined valuation ranking variants in a descending order according to their economic value.

To calculate these parameters the STABLE software of Louisiana State University Agricultural Center, Baton Rouge, USA was used. The following model was applied to assess the stability of various variants in their interaction with years:

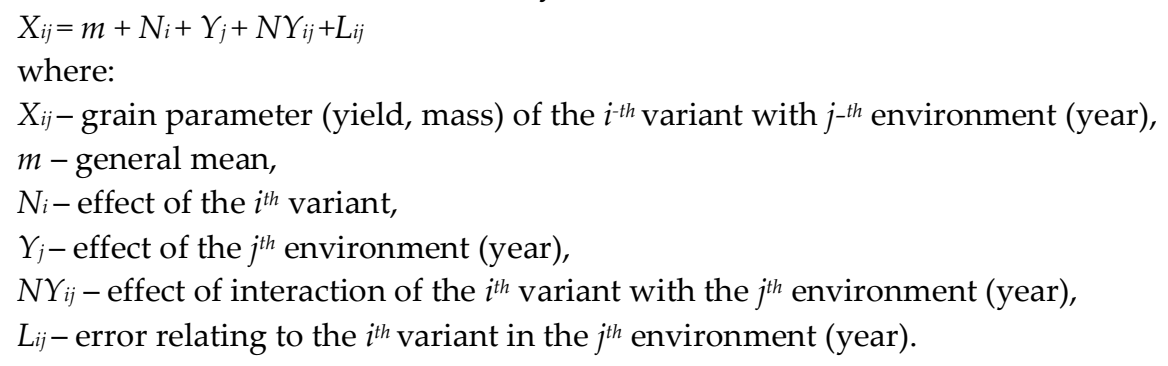

\section{Results}

On average during the study period, the herbicide Basagran 480 SL applied during cotton vegetation showed the highest phytotoxicity on fat content in seeds of the Chirpan-539 cultivar (Table 2). In it the lowest value of the indicator was measured compared to the other cultivars $28.6 \%$. The weakest is the effect of the herbicide Philipopolis. It has the highest fat content in seeds $33.6 \%$.

The herbicide Pulsar 40 has the strongest phytotoxic effect on fat content in seeds of Dorina cultivar - 23.1\%. The cultivars Helius and Darmy have the highest values of the indicator compared to the other cultivars $-28.0 \%$ and $28.4 \%$, respectively. These results show that the herbicide has the weakest effect on fat content in seeds of these cultivars.

In the vegetative treatment with the herbicide Express 50 WG the highest phytotoxicity on the fat content of seeds was recorded in the Nelina, Dorina and Darmy cultivars. In them the lowest values were measured. $29.4 \%$. 29.5\% and $29.5 \%$, respectively. The herbicide has the weakest effect on the fat content in seeds in the Helius cultivar - $32.5 \%$.

The variance analysis of fat content in cotton seeds (Table 3) revealed that herbicides have the greatest impact on this indicator $-37.0 \%$ of the total variation. The reason for this is the phytotoxic action of some herbicides on cotton plants during vegetation. Years also have a great impact - $15.8 \%$ which is due to the different weather conditions throughout individual years of study. The degree of

Table 2. Fat content in cotton seeds of vegetation treatment with herbicides, \% (2013 - 2015).

\begin{tabular}{lccccc}
\hline Herbicides & Cultivars & $\mathbf{2 0 1 3}$ & $\mathbf{2 0 1 4}$ & $\mathbf{2 0 1 5}$ & Mean \\
\cline { 2 - 6 } & Chirpan-539 & 28.1 & 30.5 & 27.1 & 28.6 \\
& Helius & 29.0 & 32.0 & 28.0 & 29.7 \\
& Trakia & 31.6 & 31.6 & 30.6 & 31.3 \\
& Vicky & 32.0 & 32.5 & 31.0 & 31.8 \\
& Philipopolis & 34.3 & 33.1 & 33.3 & 33.6 \\
& IPK-Veno & 31.3 & 31.7 & 30.3 & 31.1 \\
& Boyana & 32.1 & 33.5 & 31.1 & 32.3 \\
& Avangard & 33.6 & 31.4 & 32.6 & 32.5 \\
& Natalia & 32.0 & 33.3 & 31.0 & 32.1 \\
& Darmy & 33.1 & 32.2 & 32.1 & 32.5 \\
& Dorina & 34.1 & 30.8 & 33.1 & 32.7 \\
\hline
\end{tabular}




\begin{tabular}{|c|c|c|c|c|c|c|}
\hline \multirow{12}{*}{ Pulsar } & Chirpan-539 & 28.2 & & 29.8 & 23.2 & 27.0 \\
\hline & Helius & 29.2 & & 30.7 & 24.2 & 28.0 \\
\hline & Trakia & 25.6 & & 30.4 & 20.1 & 25.4 \\
\hline & Vicky & 29.0 & & 28.9 & 23.3 & 27.0 \\
\hline & Philipopolis & 28.7 & & 30.3 & 14.0 & 24.3 \\
\hline & IPK-Veno & 29.9 & & 30.9 & 14.3 & 25.0 \\
\hline & Boyana & 29.5 & & 31.9 & 18.2 & 26.5 \\
\hline & Avangard & 28.9 & & 30.0 & 21.9 & 26.9 \\
\hline & Natalia & 28.8 & & 28.0 & 23.6 & 26.8 \\
\hline & Darmy & 29.0 & & 30.3 & 26.0 & 28.4 \\
\hline & Dorina & 29.0 & & 26.5 & 14.0 & 23.1 \\
\hline & Nelina & 29.0 & & 29.2 & 20.8 & 26.3 \\
\hline \multirow{12}{*}{ Express } & Chirpan-539 & 32.1 & & 31.8 & 32.1 & 32.0 \\
\hline & Helius & 33.5 & & 30.6 & 33.5 & 32.5 \\
\hline & Trakia & 31.5 & & 30.8 & 32.0 & 31.4 \\
\hline & Vicky & 30.0 & & 31.1 & 30.0 & 30.3 \\
\hline & Philipopolis & 30.5 & & 30.1 & 30.4 & 30.3 \\
\hline & IPK-Veno & 30.1 & & 31.1 & 30.1 & 30.4 \\
\hline & Boyana & 29.9 & & 31.3 & 29.8 & 30.3 \\
\hline & Avangard & 32.3 & & 29.8 & 32.6 & 31.5 \\
\hline & Natalia & 30.7 & & 30.0 & 30.7 & 30.5 \\
\hline & Darmy & 29.6 & & 29.4 & 29.6 & 29.5 \\
\hline & Dorina & 29.7 & & 29.2 & 29.7 & 29.5 \\
\hline & Nelina & 29.3 & & 30.7 & 28.2 & 29.4 \\
\hline LSD, \%: & & & $\mathrm{AxB}$ & $\mathrm{p} \leq 0.05=0.2$ & $\mathrm{p} \leq 0.01=0.3$ & $\mathrm{p} \leq 0.001=0.4$ \\
\hline F.A $p \leq 0.05=0.1$ & $\mathrm{p} \leq 0.01=0.2$ & $\mathrm{p} \leq 0.001=0.3$ & $\mathrm{AxC}$ & $\mathrm{p} \leq 0.05=0.4$ & $\mathrm{p} \leq 0.01=0.6$ & $\mathrm{p} \leq 0.001=0.7$ \\
\hline F.B $p \leq 0.05=0.1$ & $\mathrm{p} \leq 0.01=0.2$ & $\mathrm{p} \leq 0.001=0.3$ & $\mathrm{BxC}$ & $\mathrm{p} \leq 0.05=0.4$ & $\mathrm{p} \leq 0.01=0.6$ & $\mathrm{p} \leq 0.001=0.7$ \\
\hline F.C $\mathrm{p} \leq 0.05=0.2$ & $\mathrm{p} \leq 0.01=0.3$ & $\mathrm{p} \leq 0.001=0.4$ & $\mathrm{AxBxC}$ & $\mathrm{p} \leq 0.05=0.7$ & $\mathrm{p} \leq 0.01=1.0$ & $\mathrm{p} \leq 0.001=1.2$ \\
\hline
\end{tabular}

effect of cultivars is $1.8 \%$. The effect of years, cultivars and herbicides is very well proven at $\mathrm{p} \leq 0.1$. There is a proven interaction of herbicides with the conditions of years $(\mathrm{AxB})-24.1 \%$, the effect of years with cultivars $(\mathrm{AxC})$ is $4.1 \%$ and that of herbicides with cultivars $(\mathrm{BxC})-8.7 \%$. They are very well proven at $\mathrm{p} \leq 0.1$. There is also interaction between the three factors in the experiment $(\mathrm{AxB} \times \mathrm{C})$ $8.0 \%$. It is also proven at $\mathrm{p} \leq 0.1$.

Table 3. Analyses of variance for fat content.

\begin{tabular}{|c|c|c|c|c|}
\hline Source of variation & $\begin{array}{c}\text { Degrees of } \\
\text { freedom }\end{array}$ & Sum of squares & $\begin{array}{c}\text { Influence of } \\
\text { factor, } \%\end{array}$ & Mean squares \\
\hline Total & 215 & 3273.3 & 100 & - \\
\hline Tract of land & 1 & 0.06 & 0.1 & 0.06 \\
\hline Variants & 107 & 3258.8 & 99.5 & $30.5 * * *$ \\
\hline Factor A - Years & 2 & 516.7 & 15.8 & $256.4 * * *$ \\
\hline Factor B - Herbicides & 2 & 1207.7 & 37.0 & $603.8 * * *$ \\
\hline Factor C - Cultivars & 11 & 59.6 & 1.8 & $5.4 * * *$ \\
\hline $\mathrm{AxB}$ & 4 & 789.4 & 24.1 & $197.4 * * *$ \\
\hline $\mathrm{AxC}$ & 22 & 135.6 & 4.1 & $6.2 * * *$ \\
\hline $\mathrm{BxC}$ & 22 & 286.3 & 8.7 & $13.0 * * *$ \\
\hline $\mathrm{AxBxC}$ & 44 & 263.5 & 8.0 & $6.0 * * *$ \\
\hline Pooled error & 107 & 14.4 & 0.4 & 0.1 \\
\hline
\end{tabular}

By using these three stability indicators it has been found that in vegetative treatment with the herbicide Basagran 480 SL stable are the following cultivars: Trakia, Vicky, IPK-Veno and Darmy (Table 4). In treatment with Pulsar 40 stable are the cultivars Vicky and Darmy with the Express 50 WG stable are the cultivars Chirpan-539, Trakia, Philipopolis, Natalia, Darmy and Dorina. The other variants have high instability. In them Shukla's stability variance values $\sigma_{i}{ }^{2}$ and $S_{i}{ }^{2}$ and Wricke's ecovalence $\mathrm{W}_{\mathrm{i}}$ are high and mathematically proven. Instability is mainly due to the significant 
differences in the fat content of seeds in these variants throughout the years of the experiment since herbicides have the strongest effect on them. In some of them there is instability of linear and non-linear type - proven values of $\sigma_{i}^{2}$ and $\mathrm{Si}^{2}$. In another part there is only instability of a linear type proven value of $\sigma_{\mathrm{i}}^{2}$ the $\sigma_{\mathrm{i}}^{2}$ и $\mathrm{Si}^{2}$ values are unproven.

Kang's $Y S_{i}$ aggregate stability criterion taking into account both the stability and the value of fat content in seeds gives negative values of cultivars Chirpan-539, Trakia, Vicky, Philipopolis, IPK-Veno, Avangard, Natalia, Dorina and Nelina, treated with Pulsar 40. They are characterized as the most unstable or the most sensitive to the herbicide regarding fat content in cotton seeds. In vegetative treatment with the herbicides Basagran 480 SL and Express 50 WG none of the cultivars received a negative evaluation. According to this criterion the most valuable in terms of fat content in cotton seeds are all cultivars with vegetative treatment with the herbicide Basagran 480 SL except Chirpan-539 and Helius. In treatment with the herbicide Express 50 VG the most valuable are Chirpan-539, Helius, Trakia, Vicky, Philipopolis, IPK-Veno, Boyana, Avangard and Natalia. They combine high values and high stability with regard to fat content in seeds throughout the years. In vegetative treatment with Pulsar 40 none of the cultivars was highly rated.

\section{Discussion}

Genetically improved cultivars and hybrids resistant to herbicides are widely used in many field crops in the world. These cultivars and hybrids are not GMOs and they are used within the territory of the all European Union. In Bulgaria with their help are solved the problems of secondary weed infestation in field crops such as sunflower, maize, canola [9].

Table 4. Stability parameters for the variants for fat content with relation to years.

\begin{tabular}{|c|c|c|c|c|c|c|}
\hline Herbicides & Cultivars & $\overline{\mathbf{x}}$ & $\sigma_{i}^{2}$ & $\mathbf{S}_{\mathbf{i}^{2}}$ & $\mathbf{W}_{\mathbf{i}}$ & $\mathbf{Y S} \mathbf{S}_{\mathrm{i}}$ \\
\hline \multirow{12}{*}{ Basagran } & Chirpan-539 & 28.6 & $2.7 * *$ & $5.1 * *$ & 6.1 & 2 \\
\hline & Helius & 29.7 & $3.9 * *$ & $8.1 * *$ & 8.2 & 10 \\
\hline & Trakia & 31.3 & $3.3^{* *}$ & -0.07 & 7.1 & $19+$ \\
\hline & Vicky & 31.8 & $2.5 * *$ & 0.08 & 5.6 & $22+$ \\
\hline & Philipopolis & 33.6 & $6.6^{* *}$ & $1.5 * *$ & 13.3 & $31+$ \\
\hline & IPK-Veno & 31.1 & $2.6^{* *}$ & 0.01 & 5.9 & $18+$ \\
\hline & Boyana & 32.3 & $1.9 * *$ & $1.6^{* *}$ & 4.6 & $25+$ \\
\hline & Avangard & 32.5 & $10.9 * *$ & $4.9 * *$ & 21.5 & $27+$ \\
\hline & Natalia & 32.1 & $2.0 * *$ & $1.3^{* *}$ & 4.7 & $24+$ \\
\hline & Darmy & 32.5 & $2.9 * *$ & -0.06 & 6.1 & $30+$ \\
\hline & Dorina & 32.7 & $17.2 * *$ & $11.0 * *$ & 33.5 & $29+$ \\
\hline & Nelina & 32.4 & $7.3 * *$ & $2.1 * *$ & 14.8 & $26+$ \\
\hline \multirow{12}{*}{ Pulsar } & Chirpan-539 & 27.0 & $4.9 * *$ & $1.2 * *$ & 10.1 & -2 \\
\hline & Helius & 28.0 & $4.6^{* *}$ & $1.0^{* *}$ & 9.5 & 0 \\
\hline & Trakia & 25.4 & $25.3 * *$ & $17.9 * *$ & 48.8 & -7 \\
\hline & Vicky & 27.0 & $3.5 * *$ & 0.3 & 7.5 & -2 \\
\hline & Philipopolis & 24.3 & $105.6^{* *}$ & 0.02 & 200.4 & -9 \\
\hline & IPK-Veno & 25.0 & $115.6^{* *}$ & 0.04 & 219.2 & -8 \\
\hline & Boyana & 26.5 & $61.7 * *$ & $1.9 * *$ & 117.5 & -5 \\
\hline & Avangard & 26.9 & $12.7 * *$ & 0.2 & 24.8 & -3 \\
\hline & Natalia & 26.8 & $1.7 * *$ & $1.4^{* *}$ & 4.2 & -4 \\
\hline & Darmy & 28.4 & 0.1 & $0.9 * *$ & 1.2 & 9 \\
\hline & Dorina & 23.1 & $80.8 * *$ & $13.9 * *$ & 15.35 & -10 \\
\hline & Nelina & 26.3 & $16.8^{* *}$ & 0.08 & 32.8 & -6 \\
\hline \multirow{9}{*}{ Express } & Chirpan-539 & 32.0 & $8.0^{* *}$ & 0.09 & 16.1 & $23+$ \\
\hline & Helius & 32.5 & $20.7 * *$ & $8.1 * *$ & 40.1 & $27+$ \\
\hline & Trakia & 31.4 & $12.1 * *$ & 0.3 & 23.8 & $20+$ \\
\hline & Vicky & 30.3 & $5.1 * *$ & $1.1 * *$ & 10.7 & $15+$ \\
\hline & Philipopolis & 30.3 & $7.9 * *$ & 0.08 & 15.8 & $13+$ \\
\hline & IPK-Veno & 30.4 & $5.3^{* *}$ & $0.9 *$ & 10.9 & $16+$ \\
\hline & Boyana & 30.3 & $4.6^{* *}$ & $1.8 * *$ & 9.6 & $13+$ \\
\hline & Avangard & 31.5 & $20.8 * *$ & $6.3^{* *}$ & 40.2 & $21+$ \\
\hline & Natalia & 30.5 & $9.4 * *$ & 0.4 & 18.6 & $17+$ \\
\hline
\end{tabular}




\begin{tabular}{lllccc} 
Darmy & 29.5 & $7.7^{* *}$ & -0.03 & 15.6 & 6 \\
Dorina & 29.5 & $8.7^{* *}$ & 0.2 & 17.3 & 7 \\
Nelina & 29.4 & $1.8^{* *}$ & $1.6 * *$ & 4.2 & 5 \\
\hline
\end{tabular}

$\overline{\mathrm{x}}$ - General mean; $\sigma_{\mathrm{i}}{ }^{2}$ and $\mathrm{S}_{\mathrm{i}}{ }^{2}$ - Shukla's stability variances; $\mathrm{W}_{\mathrm{i}}$ - Wricke's ecovalence; $\mathrm{YS}_{\mathrm{i}}$ - Kang's stability criterion.

Secondary weed infestation with annual and perennial broadleaf weeds is a huge problem for the cotton fields in Bulgaria. To combat these weeds are made 3-4 hands hoeing with hoes. They are very heavy, labor intensive, and greatly increase the cost of cotton production. Until now, this has made Bulgarian cotton production unprofitable and it could not compete with cheap GMO cotton produced in the major cotton-producing countries outside Europe. We emptied significant number of studies to find cotton cultivars resistant to foliar-applied antibroadleaf herbicides. For the first time in the world cotton cultivars resistant to herbicides Basagran 480 SL (bentazone), Pulsar 40 (imazamox) and Express 50 VG (tribenuron-methyl) have been established. These cultivars are Bulgarian and have been created in the Field Crops Institute, Chirpan. They produce high and stable yields of raw cotton, cotton fiber and cotton seeds over the years [3,4]. The use of the herbicides Bentazone, Imazamox and Tribenuron-methyl in cotton provides complete control of late spring annual broadleaf weeds Xanthium strumarium L., Amaranthus retroflexus L., Amaranthus albus L., Amaranthus blifoides W., Chenopodium album L., Solanum nigrum L., Datura stramonium L., Polygonum aviculare L., Abutilon teophrasti Medic., Portulaca oleracea L., Polygonum aviculare L., Hibiscum trionum L., Tribulus terrestris L. The herbicides Imazamox and Tribenuron-methyl also provide complete control of the perennial broadleaf weeds Cirsium arvense Scop. and Convolvulus arvensis L. [3].

The obtained results are of great importance not only for Bulgaria but also for the other countries producing cotton in the European Union - Greece, Italy, Spain and Portugal, who cannot use genetically modified cotton cultivars. This requires a study of the quality indicators of the fiber and seeds of these genetically improved cultivars resistant to herbicides. The herbicide Basagran 480 $\mathrm{SL}$, applied during cotton vegetation has the highest phytotoxicity on fat content in cotton seeds of Chirpan-539 cultivar. The highest fat content is reported for the Philipopolis cultivar. The herbicide Pulsar 40 has the strongest phytotoxic effect on fat content of cotton seeds of the Dorina cultivar. Cultivars Helius and Darmy have the highest fat content in seeds. In vegetative treatment with the herbicide Express $50 \mathrm{WG}$, the highest phytotoxicity on the fat content in seeds was recorded in cultivars Nelina, Dorina and Darmy. The weakest is the effect of the herbicide on that indicator in Helius cultivar. For the first time in the world it has been established that in the vegetative treatment with herbicides the most valuable with regard to cottonseed fat content are all cultivars treated with Basagran 480 SL, except Chirpan-539 and Helius. This shows that herbicides affected differently as the yield of cotton and the amount of fat in cottonseed. This should be taken into account when these seeds are used to produce cottonseed oil. Herbicides that reduce the fat content should not be used in the respective cultivars.

The analysis of variance for fat content showed that the herbicidal action strongly depends on weather conditions during the vegetation period. These are mainly temperature and rainfall after the herbicide treatment. Cotton cultivars also react differently when treated with herbicides Basagran, Pulsar and Express in different years.

Based on the proven interactions of herbicide $x$ year and cultivar $x$ year the stability of manifestation of each variant has been assessed with regard to fat content in cotton seeds. Shukla's stability variances $\sigma_{i}{ }^{2}$ и $\mathrm{Si}^{2}$, Wricke's ecovalence $W_{i}$ and the Kang's $Y_{\mathrm{i}}$ stability criterion have also been calculated.

Shukla's stability variances $\left(\sigma_{i}{ }^{2}\right.$ and $\left.\mathrm{Si}^{2}\right)$ which take into account both linear and non-linear interactions uniquely assess the stability of variants. The variants with lower values are considered to be more stable because they interact less with environmental conditions. The negative values of the indicators $\sigma_{\mathrm{i}}{ }^{2}$ and $\mathrm{Si}^{2}$ are assumed to be 0 . In reliably high values of either parameter $-\sigma_{\mathrm{i}}{ }^{2}$ or $\mathrm{Si}^{2}$ the variants are considered to be unstable. With Wricke's ecovalence $W_{i}$ the higher the values of the indicator the more unstable the relevant variant. 
In order to make an overall assessment of the effectiveness of each herbicide both its effect on fat content and its stability - reaction of cotton cultivars to it throughout the years - should be taken into account. Very valuable information about the technological value of variants is given by Kang's $Y S_{i}$ criterion for simultaneous evaluation of seed fat content and stability based on the reliability of differences in the fat content and the variance of interaction with the environment. The value of this criterion is that by using non-parametric methods and statistical proof of differences. We obtain a generalized assessment ranking variants in descending order according to their economic value.

It has been established for the first time that from the point of view of growing technology with vegetative treatment with the herbicide Express $50 \mathrm{WG}$, the most valuable are the cultivars Chirpan-539, Helius, Trakia, Vicky, Philipopolis, IPK-Veno, Boyana, Avangard, Natalia.

None of the cultivars is highly rated when treated with the herbicide Pulsar 40 with regard to fat content in seeds.

Author Contributions: T. Barakova: acquisition, analysis and interpretation of data, drafting of the manuscript; Gr. Delchev: statistical analysis, critical revision of the manuscript for important intellectual content, supervising the work, coordinating the research project; N. Valkova: creator of investigated cultivars, obtaining funding, administrative, technical and material support.

Conflicts of Interest: The authors declare no conflict of interest.

\section{References}

1. Ataullaev, A.; Sultanbekova, D.; Kim, M. Properties of promising cotton cultivars. Oil industry (Maslo-jirovaya promishlenost), 1982, 11, 19-21.

2. Ashok, Y. Integrated control of weeds in cotton. Environment and Ecology, 2006, 24 S (Special 3A), 883-885.

3. Barakova, T. Development of elements of integrated weed control in cotton vegetation and testing of cotton genotypes (Gossypium hirsutum L.) for resistance to herbicides, PhD Theses, Chirpan, Bulgaria, 2017, pp.164.

4. Barakova, T.; Delchev, G. Selectivity and stability of vegetation-applied herbicides at cotton (Gossypium hirsutum L.). Agricultural Science and Technology, 2016, 8 (2), 121-126.

5. Barov, V. Analysis and schemes of field experience. NAPS, Sofia, Bulgaria, 1982.

6. Chachalis, D.; Galanis, M. Weed control and cotton response to combinations of acetochlor with fluometuron. Journal of Food, Agriculture \& Environment, 2007, 5 (3/4), 198-201.

7. Constantine, D. Biodiesel from cotton seed. International Journal of Vehicle Design, 2007, 45 (1-2), 200-221.

8. Cardoso, G.D. Critical periods of weed control in naturally green colored cotton BRS Verde. Industrial Crops and Products, 2011, 34, 1198-1202.

9. Delchev, Gr. Chemical control of weeds and self-sown plants in eight field crops. Monograph, LAP LAMBERT Academic Publishing, Saarbrücken, Germany, 2018, pp. 397, ISBN: 978-613-7-43367-6.

10. Gao, X. The effect of different mixed herbicides in controlling weeds. China Cotton, 2005, 32, 19-23.

11. Gaylon, D.; Morgan, P.; Baumann, A.; Dotray, P. Weed Management in Texas Cotton. Texas A\&M Agrilife extension esc-008, 2015, 3/14.

12. Hakoomat, A. Growth and seed cotton yield as affected by cultural and chemical weed control measures in conventional planted cotton. Indus Cotton, 2005, 2, 178-182.

13. Kang, M. Simultaneous selection for yield and stability: Consequences for growers. Agronomy Journal, 1993, 85, 754-757.

14. Lidanski, T. Statistical methods in biology and agriculture, Sofia, Bulgaria, 1988.

15. Saldzhiev, I.; Valkova, N.; Stoilova, A.; Panayotova, G.; Delchev, G.; Radevska, M.; Dechev, V. Cotton yield, biomass and oil content at Bulgarian cotton cultivars. National Conferenceenergy crops in Bulgaria, 2008, 5-10. 
16. Saldzhieva, A.; Valkova, N.; Saldzhiev, I.; Panayotova, G. Study on oil potential of Bulgarian cotton cultivars as an alternative source of biofuel. Journal of International Scientific Publication: Ecology and Safety, 2009, 3 (1), 354 - 361.

17. Shukla, G. Some statistical aspects of partitioning genotype - environmental components of variability. Heredity, 1972, 29, 237-245.

18. Shanin, Y. Methodology of field experience. BAS, Sofia, Bulgaria, 1977.

19. Spielman, D.; Nazali, H.; Zambrano, X.; Zardi, P. Technological opportunity, regulatory uncertainty and Bt cotton in Pakistan. AgBioForum, 2015, 18 (1), 98-112.

20. Uzunova, G. Investigation on glyceride oil from seeds of new Bulgarian cotton cultivars and technological exploration about its derivation, shrewdness and utilization. PhD Theses, Bulgaria, 2008.

21. Wricke, G. Über eine Methode zur Erfassung der ökologischen Streckbarkeiten Feldersuchen. Pflanzenzurecht, 1962, 47, 92-96. 